\title{
Economic or Geopolitical? Explaining the Motives and Expectations of the Eurasian Economic Union's Member States
}

\author{
Artem Patalakh ${ }^{1}$ (D)
}

Received: 26 January 2017/Accepted: 8 August 2017/Published online: 23 August 2017

(C) Fudan University 2017

\begin{abstract}
The essay proceeds from the assumptions that for a economic/political integration group to succeed, first, its participants' motives should ideally be as alike as possible and not oppose one another and, second, their expectations from integration should correspond to the organisation's capabilities. In light of these assumptions, the study endeavours to assess the Eurasian Economic Union's (EAEU) potential for stability and development. First, the author analyses the key motives that were driving its member states' decisions to enter the organisation, compares them with one another and discusses how the countries' motives influence their conduct in the union. Second, the author confronts those motives against the EAEU's activities and the general logic of interstate politics on the post-Soviet space to reckon up whether the bloc's capabilities fit with the expectations of its member countries. Finally, based on that discussion, the author speculates on how the divergence/convergence of EAEU member states' goals, as well as the (in-) feasibility of their expectations, affect the organisation's development.
\end{abstract}

Keywords Capability-expectations gap $\cdot$ Economic integration $\cdot$ Eurasian economic union $\cdot$ Post-Soviet space $\cdot$ Russian foreign policy

\section{Introduction}

Since the break-up of the Soviet Union, multitudinous regional organisations and integration groups have emerged on its ashes (for their overview, see CzerewaczFilipowicz and Konopelko 2017), a trend which Libman and Vinokurov (2012) call

Artem Patalakh

artem.patalakh@unimi.it

1 Graduate School of Social and Political Sciences, University of Milan, Via Pace 10, 20122 Milan, MI, Italy 
"holding-together" integration, defining it as "a regional integration scheme initiated by a group of countries which recently belonged to a single political and economic entity (a unitary state or a colonial empire) and which exhibit high levels of economic, political and cultural interdependency" (ibid: 12-13). Among those numerous integration projects, the recently established Eurasian Economic Union (EAEU) is frequently described as potentially most important and promising (e.g. Zagorski 2015; Czerewacz-Filipowicz and Konopelko 2017): as distinct from other post-Soviet integration groups, the EAEU arguably has a functioning Court, a more advanced system of decision making, which to a certain extent enables small states to balance Russian dominance, and a relatively powerful and adequately financed supranational institution, the Eurasian Economic Commission (Dragneva and Wolczuk 2012: 6-7; Popescu 2014: 11; Vinokurov 2017). Moreover, the evolution of integration in the EAEU heretofore does show that the bloc has relatively farreaching plans underpinned by a rather strong political will.

Given the bloc's young age, making judgements about the EAEU's actual effectiveness seems still premature, while what is possible to do already now is to analyse the union's potential by looking at its member states' motives to enter the organisation. With this regard, the main assumption is that convergence of the member states' motives generates a common vision of the bloc's future, which will make it easier to deepen and extend integration. Such motives may be of different nature. Sometimes, economic integration serves political purposes, even though leaders may skip publicly declaring such intentions: for instance, the presidents of Mercosur's member states are deemed to have mainly aimed to diminish domestic pressures to raise military expenditures, though the Treaty of Asunción, the organisation's founding document, fails to mention it (Malamud 2005: 423). In other cases, a state's intention to integrate might be driven by the desire to fulfil its identity: to illustrate, Georgia is argued to have chosen a European integration path primarily as a way to enter a club of "civilised" and advanced states and detach itself from underdeveloped, "barbaric" Russia (Kakachia and Minesashvili 2015). Just as widespread are situations when a country's desire for integration has chiefly material roots: for example, one case study shows that Serbia is striving to join the EU mainly for instrumental reasons, aiming to gain access to EU funds (Economides and KerLindsay 2015).

It appears that whatever the member nations' goals are, they should be similar or, at least, not opposing one another; otherwise, integration risks getting stuck. An ample illustration of this point is the so-called North-South divide in the EU, a term that implies that the policies benefiting the bloc's Northern part tend to harm its South (Landesmann 2015). Moreover, the member states' goals should obviously be in tune with the organisation's real abilities in terms of its budget, structure, competence, etc; otherwise, integration may get buried due to the absence of real mechanisms to fulfil the declared goals. The destinies of the above-mentioned CIS Economic Union and EurAsEC both aptly illustrate this point.

In this article, I pursue three primary objectives which correspond to its first, second, and third chapters. First, I use insight from various primary (e.g. leaders' speeches) and secondary (media and, to a lesser degree, academic publications) 
sources to find out the primary motives of the EAEU's member states ${ }^{1}$ and the ways in which those motives impact on their behaviour in the bloc. Second, I compare the motives with the EAEU's capacities to assess to what extent the organisation helps its members achieve what they aspire. Finally, I elaborate on how the divergence/convergence of the EAEU member nations' motives and the (in-) feasibility of their expectations influence the organisation's development.

For convenience, I subdivide the member countries into three categories taking into account the sequence of their accessions as well as their political and economic peculiarities, which were ultimately reflected in their motives for joining the union. The first group is comprised of solely Russia, the organisation's biggest state territorially as well as the strongest one economically and geopolitically. Russia was the key founder of the bloc and, as I show below, Russia's very decision to initiate the union was mainly determined by its desire to fulfil its state identity rather than any rational assessment of economic benefits. The second group consists of the EAEU's two other co-founders, Belarus and Kazakhstan: in the union, these two authoritarian states occupy midpositions by territories, population sizes, GDPs as well as geopolitical weights. Their accedences to the EAEU were driven by a combination of pragmatic economic and ideological reasons. The third group is made of Armenia and Kyrgyzstan, the EAEU's newest members which are both relatively democratic and, at the same time, weak and small. Their motives to accede to the EAEU lied were economy driven and security driven; moreover, unlike Belarus and Kazakhstan which joined the union voluntarily, these two countries experienced substantial Russian pressure, without which their accessions would have been unlikely to happen.

\section{EAEU Member States' Goals in Integration Process}

\subsection{Russia}

There is a widely held feeling that the genuine motives that induced Russia to reactivate Eurasian integration lied far away from the economic sphere. The very logic of the Russian foreign policy in 2014-2015 shows that it was prioritising geopolitics over economic and trade development: its policies in Ukraine and a subsequent war of sanctions with the EU considerably undermined Russia's foreign trade, with a number of high-ranked Russian officials arguing that Crimea and the national glory were worth sacrificing material prosperity (The Moscow Times 2015). Lastly, a look at President Putin's key speeches makes it clear that for him personally, geopolitics matters more than the national economy. For instance, in his annual presidential addresses, the Eurasian integration does not receive much attention and is discussed after a detailed description of geopolitical issues (see

\footnotetext{
${ }^{1}$ It is noteworthy that I focus on the states' primary motives, i.e. the key factors that determined their accession to the EAEU; I do not endeavour to list all the benefits that an EAEU membership could potentially give them.
} 
Putin 2014, 2015). ${ }^{2}$ The few exceptions, such as his flagship article on the EAEU in Izvestiya newspaper (Putin 2011), which are mainly devoted to economic matters, date back to the period when he was Prime Minister and thus was mainly dealing with economics.

Naturally, there exist alternative explanations positing that Russia was principally guided by socio-economic considerations. For instance, Russian officials argue that the EAEU's power lies in the elimination of barriers for businessmen and its great long-term economic potential (Falyakhov 2014). Another assumption is that by integrating, Russia intended to learn from its partners' success in certain spheres (Popescu 2014: 15): for instance, Armenia, Belarus and Kazakhstan have less corruption and better business environments than Russia (Transparency International 2017; World Bank 2017: 7), and Kazakhstan surpasses Russia in the Global Competitiveness Index (Schwab and Sala-i-Martín 2015: xv). However, the socioeconomic argument appears weak and insufficient, given that in the recent years, the Kremlin has been reluctant to internalise international norms against corruption (Quinn 2015; Reiter and Osborn 2017), diminish legal barriers and simplify bureaucratic procedures for investors (Komrakov 2016). Therefore, it appears fairer to argue that Putin did expect certain economic benefits from the integration; however, those benefits hardly were his main motive.

Therefore, I side with constructivist scholars who argue that Russia's integration initiatives were geopolitically driven and rooted in the country's contemporary identity (e.g. Kazharski 2013; Morozova 2011): from this viewpoint, the EAEU's creation chiefly stemmed from Moscow's desire to counter the EU. A strong argument in favour of this point is that although Eurasian integration was actively furthered by Kazakhstan from 1994 onwards, Russia was remaining somewhat listless on it until the EU's launch of Eastern Partnership in 2009, which caused Moscow's fear that the Eastern Partnership member countries would eventually drift from Russia's "zone of influence" towards the EU (Cadier 2014). Hence, Moscow was regarding the Eurasian integration as an instrument to fulfil Russia's antiWestern identity which has gradually evolved since the late 1990s. One can roughly single out three phases of its development. During the first phase (late 1990s-mid 2000s), Russia perceived itself as a member of European nations' family and wanted to integrate into Western structures, occasionally criticising the West's policies for allegedly not accounting for Russian interests (e.g. concerning the eastwards expansion of NATO, the 1999 bombings of Yugoslavia, the 2003 Iraqi war.). In the second phase (from the mid-2000s till 2012-2013), the Kremlin tried to compete with the West by playing according to the international (mainly Western) rules of the game. At that period, Russia was blaming the West for violating its own standards (e.g. Russia's Foreign Ministry was issuing annual reports on human rights abuses in Western countries) and invented the "sovereign democracy" concept which meant that democracy existed in Russia, but with certain national peculiarities. Finally, in the third phase (2013 - present), Russia has been in a fierce

\footnotetext{
${ }^{2}$ Putin's preoccupation with geopolitics especially manifests itself against the backdrop of Kazakh President Nazarbayev and Belarusian President Lukashenko whose annual addresses are primarily dedicated to socio-economic issues (e.g. Lukashenko 2016; Nazarbayev 2015).
} 
opposition to the West, its values, ideas, norms (including democracy and human rights) with its official discourse arguing that Russia is a self-sufficient civilisation that does not have to comply with Western standards (Silvius 2014). Such statements occasionally occurred in the past as well, but were primarily made by marginal politicians, whereas the official discourse during Medvedev's presidency (2008-2012) was in large part devoted to modernising the national economy, overcoming legal nihilism, fighting corruption, liberalising the penal code, reforming the police, etc. Contrariwise, in Putin's new presidential term, on the foreground have been topics of a clearly anti-Western character, such as adoption of new prohibitive bills, support of orthodoxy and Russian traditional values and intolerance towards homosexuality. Interestingly, both transitions to the subsequent phases are considered to have stemmed from Putin's fear of colour revolutions: what arguably impelled him to tighten the screws was the Ukrainian 2004 Maidan revolution and the 2011-2012 protests in Moscow (Togt et al. 2015: 28-29).

The identity argument presupposes that it is a logic of appropriateness ${ }^{3}$ rather than a rational calculation of benefits that induced Russia to initiate the EAEU: claiming to be a self-sufficient civilisation, Russia had to demonstrate that other nations consider it a pole of attraction and integration. Identity construction often implies the existence of the Other; in this case, this Other was the West in general and the EU in particular. Remarkably, in 2010-2012, when Russia was at the second stage of its anti-Western identity evolution, the Kremlin was considering the EAEU and the EU as complementary projects, announcing the desire to cooperate with the EU on condition of being treated equally and not as an inferior partner:

[s]oon the Customs Union, and later the Eurasian Union, will join the dialogue with the EU. As a result, apart from generating direct economic benefits, accession to the Eurasian Union will also help countries integrate into Europe sooner and from a stronger position (Putin 2011).

At that stage, Russia kept proposing the EU to cooperate, sometimes going as far as proposing to create a common free trade area (Putin 2011; Vinokurov 2014). Later, as Russia's anti-Western identity deepened and the EU started to be officially depicted more negatively, suggestions to integrate have not been made anymore.

That Russia treats the EAEU in geopolitical rather than developmental terms impacts on its approach to integration. First, Moscow wants to attract as many countries as possible with little account for possible economic consequences and compliance with the union's own norms. For instance, Russia tried to make Armenia enter the EAEU by all means, neglecting the provision of bloc's treaty which states that only a country, that borders on at least one of its actual member states, can join the organisation (Engvall 2014: 115). Second, Moscow keeps calling upon integration to be speeded up and extended, making little allowance for possible developmental benefits from such measures. In doing so, Moscow most likely tries to show Brussels that the Eurasian integration project compares well

\footnotetext{
3 In sociological institutionalism, a logic of appropriateness is a term that interprets decision making as biased towards social rules and norms that guide the appropriate behaviour for a certain role or identity (March and Olsen 1995).
} 
with the EU. Economically reasoning, it would make more sense to integrate less rapidly, but more firmly, which Kazakhstan's President Nazarbayev once explicitly told Putin (Daly 2014: 88-89). Third, in expanding integration and imitating the EU, Moscow eventually plans to politicise the EAEU by including a number of foreign policy aspects, border control and migration in the spheres of its competence (Popescu 2014: 21). Behaving this way, Moscow may desire to increase its control over its partners, given the fact that Russian officials already dominate the staff of the Eurasian Economic Commission (Sivickiy 2015: 16). Finally, in attracting new members to the union, Russia largely relies not only on soft, but also hard power, which in practice implies resorting to threatening (see examples below) and, in the extreme cases, punishing "non-compliant" states with military intervention and territorial annexation, as it happened with Ukraine in 2014.

\subsection{Belarus and Kazakhstan}

While Russia's behaviour can to a large extent be explained by reference to the logic of appropriateness rooted in its state identity, Belarus and Kazakhstan's memberships in the EAEU are the results of the rational calculation of instrumental benefits related to their domestic development. Some of those benefits are nonmaterial: for instance, in Kazakhstan, Eurasian ideas have been ideologically important since the mid-1990s with the rhetoric of Kazakhstan as a bridge between Europe and Asia being widely employed by President Nazarbayev. Kazakh political scientist Mostafa Golam argues (2013: 169, emphases added) that the ideology of Eurasianism in Kazakhstan serves three primary goals:

[i]nternationally, it helps the state to develop and maintain balanced and friendly relations with all major states and blocs; regionally it is used as a vehicle and policy guideline for creating and deepening the integration process at the post-Soviet space; domestically, the policy of Eurasianism is used for consolidating national integration, national-building and creating national consensus and harmony among the different segments of population.

Hence, the main difference between Nazarbayev's and Putin's Eurasianisms lies in their foreign policy implications: unlike his Russian counterpart, the Kazakh leader is usually described as a more pragmatic leader whose ambitions are oriented towards domestic modernisation and who has little intention to engage in a geopolitical confrontation with the West (Popescu 2014: 21-22; Shendrikova 2015: 16). In his own words, "[e]conomic interests, rather than abstract geopolitical ideas and slogans, are the main driving force of integration processes", (Nazarbayev 2011). In particular, when it comes to non-economic issues, Nazarbayev endeavours to win by playing according to international norms rather than challenging them. Driven by economic considerations, Kazakhstan pursues a genuinely multi-vector foreign policy, trying to achieve international recognition rather than improve its ties with some countries at the expense of its relations with others (Engvall and Cornell 2015: 67-72). Intending to keep good relations with the West, Astana not only refused to officially recognise Russia's annexation of Crimea, but also took efforts to resolve the Russian-Ukrainian conflict in 2014 (ibid). Also, while Russia 
is positioning itself as a strong opponent of LGBTI rights domestically and abroad, Kazakhstan behaves far more neutrally. Astana rejected a Russian-like law criminalising homosexual "propaganda", a step which was largely interpreted through the prism of Kazakhstan's desire to host the 2022 Winter Olympics (Putz 2015). On 2 October 2014, Kazakhstan's representative in the UN Human Rights Council abstained from voting on a resolution to combat violence and discrimination based on sexual orientation and gender identity, while Russia voted against it (UN Human Rights Council 2014: 2).

Unlike Nazarbayev, Belarusian President Alexander Lukashenko does not resort to the rhetoric of Eurasianism-apparently, because Belarus is geographically situated only in Europe. However, his country' membership in the Russia-led organisation perfectly fits into his domestic national identity building policies aimed to strengthen his power. Since his election as the president in 1994, Lukashenko has re-oriented Belarus' foreign policy towards Russia simultaneously promoting the ideology of Belarus being a European state, but historically, culturally and linguistically tied with Russia (Smok 2013). Similarly to the Kazakh leader and unlike Putin, Lukashenko seems to prioritise domestic economic matters over geopolitics. Along with this line, he treats Belarus-EU relations pragmatically: the EU sometimes provides financial aid to Belarus, which Lukashenko needs to keep the country's ineffective economy afloat (Sivickiy 2015). Furthermore, for Minsk, relations with the EU are an effective negotiating card with Russia: Lukashenko plays on the Kremlin's fear that Belarus may drift towards the West instead of aligning on Moscow (ibid). In 2014-2015, during the peak of the Ukrainian crisis, Lukashenko's personal ideological nonacceptance of the Ukrainian revolution of dignity was not preventing him from keeping relations with Ukraine good for economic reasons (BELTA 2014; Bogutsky 2015). Eventually, having friendly ties with both Kiev and Moscow enabled him to act as a mediator of the Russia-Ukraine conflict and, in the end, improve Belarus' relations with the EU. For such a policy, Lukashenko was once named "the real winner of the Ukraine crisis" (Charnysh 2014), which seems not far from reality.

The pragmatism of the Kazakh and Belarusian leaders is reflected in their attitudes to the desired pace and character of the integration. First, whereas Moscow tries to attract almost anyone, Minsk and Astana are normally sceptical about those new states that might harm their economic and security interests. For example, Kazakhstan was not enthusiastic about Kyrgyzstan's accession, since such could, first, expose its national textile manufacture to lower labour cost Kyrgyzstan (Shendrikova 2015: 17) and, second, engender an inflow of cheap Chinese goods into the EAEU market due to the corruptibility of Kyrgyz customs and the weakness of its border control (Popescu 2014: 23). Furthermore, Belarus and Kazakhstan express certain scepticism about Russia proposing to accelerate integration, accept new countries before they comply with all the conditions for accession and extend integration to new spheres without completing it in the previously agreed ones (Daly 2014: 88-89). Finally, Minsk and Astana are reluctant to the aforementioned Russian-promoted politicisation of the EAEU (ibid: 89-90, 95-96). Politically, the EAEU interests them mainly as a way to maintain balance in their foreign policies: on the one hand, they formally side with Russia, which helps them avoid possible 
conflicts, ${ }^{4}$ but at the same time, the system of decision making by consensus in the Eurasian Economic Commission enables them to mitigate Russia's influence.

\subsection{Armenia and Kyrgyzstan}

Politically, these two small countries seem black sheep in the EAEU's family: though their political systems can hardly be regarded as fully democratic and liberal, they still rest on far higher levels of democracy and pluralism, starkly contrasting to the union's other members with their forged elections, unchangeable leaders and the state-controlled mass media. ${ }^{5}$ Their rationales for joining the bloc also differed: while in the cases of Belarus and Kazakhstan, the Eurasian integration and a close cooperation with Russia are rooted in their ideologies, the leaders of Armenia and Kyrgyzstan explicitly argue that for them, the Eurasian integration has nothing to do with a "civilisation choice", but instead, is a form of pure pragmatism (Melikyan 2015: 11; Kuchins et al. 2015: 14-16). Moreover, in their cases, these pragmatic decisions were taken under strong Russian pressure, by exerting which, Moscow was exploiting its substantial economic leverage over those countries. To illustrate, in 2013, Moscow explicitly threatened Armenia that, should it decline to join the EAEU and conclude an Association Agreement with the EU instead, Russia would increase gas prices by $70 \%$, ban Armenian exports and block private transfers of money to Armenia, deport Armenians working in Russia as well as provide offensive weaponry to Azerbaijan (Grigoryan 2014: 105-106). Likewise, Moscow threatened Bishkek to tighten work conditions for Kyrgyz migrants in Russia, whose remittances make up 31\% of Kyrgyzstan's GDP (Kuchins et al. 2015: 14). ${ }^{6}$ Given that both states heavily depended on Russia, they were, in fact, not left with any other choice but to surrender to Russia's pressure. ${ }^{7}$ Their despair is best reflected in Kyrgyz President Almazbek Atambaev's statement: "You also must understand that, unfortunately, we don't have many alternatives. Ukraine can choose between

\footnotetext{
4 Some analysts (e.g. Laruelle 2015: 8-9) argue that the annexation of Crimea, made under the pretext of protecting ethnic Russians, made Minsk and Astana fear the possibility of the same scenario in their states: the north of Kazakhstan is inhabited primarily by Russians, and Russian is the most spoken language in Belarus. Arguably, this fear was the primary driver of Nazarbayev's recent policies designated to reinforce sovereignty, promote patriotism and increase the share of ethnic Kazakhs in the north of Kazakhstan.

5 To cite but a few illustrations, Freedom House (2017: 20-24) makes Armenia and Kyrgyzstan as "partly free", while the EAEU's other members - as "not free". The Economist Intelligence Unit's Democracy Index (2016: 5-9) characterises Kyrgyzstan and Armenia as "hybrid regimes", whereas the EAEU's rest —as "authoritarian" states. In the World Press Freedom Index, Armenia and Kyrgyzstan rank 79 and 89 (out of 180), while Russia, Belarus, and Kazakhstan enjoy only 148, 153, and 157 positions, respectively (Reporters Without Borders 2017).

${ }^{6}$ Incidentally, Putin also had geopolitical considerations to pull Kyrgyzstan into the EAEU: Moscow wanted to ensure Bishkek's alignment to Russia under the conditions of China's growing economic presence in Kyrgyzstan (Engvall 2014: 118-120).

7 Remarkably, the EAEU's other member states barely played any significant role in Yerevan's decision to enter the EAEU: as of 2013, the shares of Belarus and Kazakhstan in Armenia's foreign trade were less than 1\% (Grigoryan 2014: 100). Kyrgyzstan, apart from Russia, has close economic connections with Kazakhstan, which also arguably affected Bishkek's decision to join the EAEU (Kuchins et al. 2015: 5-7).
} 
association with the European Union or the customs union. Our selection is small" (cited in Coalson 2014).

It is only fair to say that Russia, on its part, partially compensated the two countries' losses from entering the EAEU. Armenia's biggest risk was that the EAEU's external tariffs for many goods were higher than those that Armenia had applied before. Given that Armenia imports about 11.500 kinds of goods and its largest trade partner is the EU (27.3\% of the overall trade volume against $22.7 \%$ for the EAEU members), an increase in tariffs implied a potentially devastating effect on Armenia's external trade (Grigoryan 2014: 100-101). To avoid it, Armenia's customs duties on certain goods were agreed to be temporarily lower than the ones that apply to the EAEU's other members (Melikyan 2015: 13-14). Bishkek, on its part, feared that increasing its external tariffs could result in the loss of Kyrgyzstan's status as the main re-exporter of Chinese goods to the neighbouring states, which traditionally was highly profitable for that country (Tarr 2016: 16). Moscow agreed to compensate those losses by creating a development fund of $\$ 500$ million; also, Russia and Kazakhstan promised to allocate a foreign aid of $\$ 1.2$ billion and $\$ 170$ million, respectively (ibid). In a nutshell, while Minsk and Astana entered the EAEU to obtain new benefits, Yerevan and Bishkek did so primarily not to lose what they had had before: the aid they obtained from Russia as a condition for their accession was chiefly to make up (at least, partially) for losses rather than provide new gains.

Besides economic considerations, the reason why the Russian pressure worked well concerned both states' security matters. Russia's general support and Russian weapons' supplies empower Armenia's position against Azerbaijan in the conflict over Nagorno-Karabakh: Armenian President Sargsyan even explicitly named security considerations the chief reason why Armenia preferred the EAEU to the EU (Melikyan 2015: 10-11). Kyrgyzstan, in its turn, needs Russian assistance against its more powerful southern neighbour Uzbekistan, with which Bishkek has disputes over territory and water management (Engvall 2014: 117-118; Kuchins et al. 2015: 15). Similarly to Belarus and Kazakhstan, these two countries host Russian military bases.

All in all, Armenia and Kyrgyzstan's motives to accede to the EAEU were economy driven and security driven. However, the crucial factor that "activated" those motives was Russia's pressure: it seems that preserving the then status quo, that is, pragmatically capitalizing on all their partners' competitive advantages (e.g. aligning to Russia militarily, while benefiting from economic cooperation with every trade partner), rather than sacrificing some partners for others' sake, would have been a more optimal policy choice for Armenia and Kyrgyzstan.

\section{Is the EAEU Paying/Going to Pay Back? A Brief Assessment}

\subsection{Russia}

Economically, Russia hardly benefits from its integration project. Indeed, the EAEU appears too costly for the Kremlin: Russia annually spends $\$ 5.2$ billion only in 
direct expenses on the union (Falyakhov 2014), while its economic effects are still uncertain: in 2015-2016, Russia's total trade volumes with Armenia, Belarus, Kazakhstan and Kyrgyzstan continuously declined (Eurasian Economic Commission 2016a, b). However, in identity-based respects, the EAEU's creation, seen in terms of challenging the West, appears to have borne fruit to Putin thus far. Domestically, anti-Westernism is highly welcomed by Russians (Simmons et al. 2015), while "gathering" post-Soviet states together perfectly corresponds to their widespread "imperial ambitions" (Kasamara and Sorokina 2012). Yet, regarding technicalities, Russians tend to show a certain discontent: for instance, most of them oppose an influx of Central Asians with $82 \%$ favouring the introduction of visas for them (Popescu 2014: 17). Internationally, the EAEU's creation has conduced to the enhancement of Russia's "conservative soft power" (on this term, see Keating and Kaczmarska 2017): Putin's self-positioning as the West's firm challenger improves his reputation among the world's conservatives that share the anti-Western standpoint. Concurrently, on the post-Soviet space, especially in Russia's EUoriented neighbours (the Baltics, Georgia, Ukraine), the emergence of a new Russialed bloc further exacerbates the existent fear that Russia endeavours to re-establish the Soviet Union. Additionally, fierce anti-Westernism faces a sort of incomprehension from Russia's pragmatically oriented fellow travellers, Belarus and Kazakhstan. Finally, from the geopolitical perspective, by creating the EAEU, Russia halted (at least, temporarily) the EU's further expansion to Armenia and growing Chinese influence in Kyrgyzstan. In pursuance of this aim, Moscow used a geoeconomic tool: since the bloc's creation, Armenia and Kyrgyzstan have already got economically closer to Russia (Eurasian Economic Commission 2016a, b), and if this trend continues (which is likely), it will make it harder for them to drift away from Russia once they want it.

It is, nonetheless, highly questionable how long this state of affairs is likely to last. One threat for Moscow is brought by the EU that has now chosen a flexible long-term strategy towards Belarus and Armenia: unlike Russia, Europe relies on soft power in relations with their governments and focuses much on their civic societies. Instead of trying to isolate Belarus, the EU has undertaken a more pragmatic and cooperative approach aiming to advance democracy and human rights in the long run: it has recently dropped sanctions against a number of highlevel Belarusian politicians and started to allocate more money on civil projects (Togt et al. 2015: 37). Europe also keeps developing its ties with Armenia, even though President Sargsyan rejected to sign an Association Agreement with the EU in 2013: besides cooperating on the reforms of Armenia's judiciary and public administration systems as well as the development of the country's private sector, the two sides concluded the Memorandum of Understanding in 2014 and are about to sign the legally binding Comprehensive and Enhanced Partnership Agreement.

Moreover, inside the EAEU, Moscow also faces threats to its hegemony. First, there is no guarantee that in the EAEU's democracies-Armenia and Kyrgyzstananti-Russian opposition parties will not one day win elections and reverse their foreign policies. The same plays out for Belarus and Kazakhstan as well: their loyalty to the Kremlin seems firm under the current leaders, but, as one Russian official said, uncertainties brought by Lukashenko's or Nazarbayev's death would 
be a nightmare for Putin (Popescu 2014: 14). Albeit so far, the populations of all the four countries have been mostly positive about the $\mathrm{EAEU}^{8}$ - in large measure due to their information spaces being dominated by the Russian media-people still reportedly tend to resent Russia for its "imperial ambitions" (e.g. see Daly 2014: 90-91; Engvall 2014: 115-116; Grigoryan 2014: 105; Kuchins et al. 2015: 12-17). However, this resentment has hitherto engendered serious anti-Russian demonstrations only in Armenia (which, however, were not systematic, but rather related to particular events). Besides "imperial ambitions", people criticise Russia for its general approach towards integration, which, unlike the EU's, rests upon providing countries with immediate benefits rather than aiming at their long-term development (e.g. de Micco 2015). Notably, in the EAEU members, Russia's image tends to be closely linked to the overall image of the EAEU, which appears destined to deteriorate in the absence of palpable material benefits: for instance, a gradual fall of Russia's image in Belarus over the two recent years has been reportedly caused, inter alia, by the fact that economic integration has not brought tangible benefits to ordinary Belarusians ${ }^{9}$ (Khodasevich 2016).

\subsection{Belarus and Kazakhstan}

The very creation of the EAEU was a big symbolic victory of Kazakhstan's foreign policy and personally President Nazarbayev, since, as was argued above, this is what he had aspired from the mid-1990s (Golam 2013). It also enabled both Lukashenko and Nazarbayev to strengthen their popularity at home: as was stated above, surveys show that in spite of the above-mentioned anti-Russian sentiments, integration with Russia is generally supported in both countries.

However, regarding technicalities, the situation seems less certainly favourable for the two leaders. The first question is if they can succeed to build a union upon the principles of economic pragmatism and non-politicisation despite Moscow's geopolitical ambitions. So far, Putin, despite Nazarbayev and Lukashenko's certain scepticism, has generally managed to bring new members to the organisation, but had to agree on the unanimity principle in the Eurasian Commission's decision making and give up his plans to introduce a single currency and extend the EAEU competence to political issues. Yet, despite these small (and, perhaps, temporary) victories, Minsk and Astana's influence on Moscow seems quite limited: their economic and energy dependence on Russia will enable Putin to reply with a hard hand should they become too disobedient. Besides, all their anti-politicisation efforts have failed to create a new image for the organisation: unlike ASEAN, Nafta and Mercosur, the EAEU is still largely considered in the world as a political rather than economic union (for relevant examples in the world's leading magazines, see Birnbaum 2014; Michel 2014; Vitkine 2014).

\footnotetext{
8 A negative trend has been observed only in Armenia, where the popular support of EAEU has dropped from $64 \%$ in 2014 to $46 \%$ in 2016 (Vinokurov 2017: 68).

9 Naturally, if Eurasian integration appears unprofitable in the long run, it will also negatively impact on the Kremlin's “conservative soft power" outside Russia's "near abroad”, giving Putin's overseas opponents an opportune reason to criticise him.
} 
The second issue concerns economic modernisation and trade. On the one hand, the EAEU's creation generated new opportunities for Belarus and Kazakhstan: in particular, it opened a huge Russian market for their companies, induced several Russian companies to relocate themselves to Kazakhstan owing to its better business climate (Togt et al. 2015: 34) and entailed removal of non-trade barriers which is expected to be beneficial for both countries in the mid-run (Vinokurov 2017: 60). At the same time, the EAEU has further strengthened economic interdependence between these states and Russia, the downside of which was that the Russian rouble's dramatic decline in 2014 triggered the depreciation of the Belarusian rouble and the Kazakh tenge as well (Libman 2015). Due to this crisis, Minsk and Astana have yet to take advantage of the EAEU common market: mutual trade volumes between these two countries and the EAEU's other member states have heretofore declinedperhaps, paradoxically (Eurasian Economic Commission 2016a, b).

Perhaps the two countries' only consolation was that Russia's obsession with geopolitics has allowed them to partially compensate these economic losses. First of all, they increased their exports to Russia to make up for Putin's anti-EU food embargo. Also, the embargo enabled Belarusian companies (apparently, with Lukashenko's connivance) to illegally re-export EU products to Russia under Belarusian labels, which caused the Russian authorities' resistance and a small customs war between the two countries in December 2014 (see Moshes 2014: 4; Boguslavska 2015: 10 for details). Finally, Belarus and Kazakhstan tend to use the lack of success in economic integration as an additional leverage over Russia, occasionally going as far as threatening Moscow to leave the bloc. Though such statements can be fairly regarded as a mere bluff, they often enable Minsk and Astana to successfully obtain additional concessions from Moscow: for instance, behaving this way, Lukashenko managed to convince Putin to give him the right to retain $\$ 1.5$ billion of its export oil duties in 2015 (Moshes 2014: 4).

\subsection{Armenia and Kyrgyzstan}

One goal (or, better said, hope) of these states was having their security guaranteed by Russia which their elites were perceiving as the only country that can do it. For the Kremlin, their accession to the EAEU was a sign of their loyalty, which Putin rewarded by keeping to sell them weaponry, maintain military bases on their territories and finance the modernisation of their armies (Engvall 2014; Grigoryan 2014). Nevertheless, it remains a big question if Russia is ready, upon necessity, to be involved in a conflict with Azerbaijan or Uzbekistan for the sake of Armenia and Kyrgyzstan. Since the USSR's break-up, Russia has been balancing between all these sides, eschewing from supporting any of them overtly, but instead, taking advantage of the existent controversies. For instance, although Russia is culturally and religiously closer tied to Armenia than Azerbaijan, Moscow still has been, to Yerevan's discontent, regularly selling weapons to Baku, ${ }^{10}$ while diplomatically

\footnotetext{
10 A recent statement by Russian Deputy Premier Dmitry Rogozin, that Russia has already sold weapons of \$4 to Baku and will continue doing so to keep NATO and the US away from the region, triggered massive anti-Russian protests in Yerevan (The Moscow Times 2016).
} 
abstaining from taking Armenia's side in the conflict over Nagorno-Karabakh. The situation did not even change when Russia-Turkey relations dramatically deteriorated in November 2015: whereas Turkey was overtly supporting Azerbaijan during the four-day war in Nagorno-Karabakh in April 2016, Russia again refrained from taking either position (Hedenskog and Korkmaz 2016). Likewise, when Kyrgyzstan, as a member of the Collective Security Treaty Organisation, officially asked Moscow to help stop Uzbek-Kyrgyz interethnic clashes in the Fergana Valley in 2010, Moscow refused it under the pretext that the CSTO can aid solely in case of a foreign intervention and not a civil conflict, which was largely interpreted as the Kremlin's unwillingness to worsen its relations with Uzbekistan (Engvall 2014: 121). Therefore, there is good reason to believe that Putin is likely to find a pretext to leave Armenia and Kyrgyzstan alone in case of a military conflict, notwithstanding that they are the CSTO's members (while Azerbaijan and Uzbekistan are not) and their leaders constantly demonstrate their loyalty to him personally (Hedenskog and Korkmaz 2016; Stratfor 2013).

As for the economic aspect of these two states' EAEU membership, when it comes to material aid and lower gas and oil prices, Russia is likely to keep compensating their economic losses by providing material aid and lowering gas and oil prices as long as they display allegiance. However, any disloyal step is likely to result in a suspension or rejection of support even when Moscow has priorly promised to provide aid. Such happened, for instance, after the 2014 Ukrainian revolution of dignity, when Russia cancelled a discount on gas for the country's new authorities, though it had been agreed on with Ukraine's ex-President Yanukovych (Rushton 2014). One year earlier, Putin behaved similarly by not paying a promised loan to Kyrgyzstan after the Bakiev administration had decided, to Moscow's discontent, to let the US continue using a military base in Manas (Engvall 2014: 120-121). Also, entering the EAEU enabled Armenia and Kyrgyzstan to keep the remittances of Armenian and Kyrgyz workers in Russia, though, due to the rouble's depreciation, their size turned out to be considerably lower than what they had expected. ${ }^{11}$ Moreover, worsening economic conditions have also triggered a general outflow of working migrants from Russia (TASS 2015).

\section{Discussion}

The presented analysis allows making a number of conclusions. First, while the EAEU's member nations do not seem to have mutually opposing intentions, however, they still appear to prioritise different things: while the motives of Russia, Armenia and Kyrgyzstan lied mainly in the political sphere, their fellow statesBelarus and Kazakhstan-however self-tautological it can sound, entered an economic integration organisation mainly to benefit from economic integration, simultaneously having certain ideological reasons. Here the trap is that whereas

\footnotetext{
11 Incidentally, the same applies to some other material benefits: to exemplify, a decrease in oil prices in the world significantly lessened the effect of the discount Russia had given Armenia and Kyrgyzstan (see Mordyushenko 2016).
} 
political goals are practically always attainable if leaders show will for that, achieving economic profitability highly depends on the factors political leaders cannot influence directly. Should economic integration continue to be seen as unprofitable, Belarus and Kazakhstan are likely to gradually lose their incentives to stay in the EAEU. However, their possible exit would be at odds with the Kremlin's self-positioning as an attractive "integrator", so, to save its face, Putin is likely to either compensate their losses materially or resort to hard power means, which he used to pull Armenia and Kyrgyzstan into the EAEU.

Second, despite having been parts of a single country for centuries, the EAEU's member states surprisingly seem not to have a common culture of interaction: besides diplomacy and soft power, what they tend to resort to is coercion and violation of the union's rules. In general, the EAEU's members appear to cooperate with each other more mainly in realpolitik terms, showing friendship chiefly when it benefits them. Most plausibly, this originates in the fact that three out of five member nations are autocracies, whose foreign policies are theorised to be affected by their domestic political culture and hence, they are not used to compromising and negotiating (see Weart 1998). Moreover, since the EAEU does not adduce any political criteria to newcomers like, for instance, does the EU, and, as a result, includes both democratic and authoritarian states, the formation of a common identity among its member nations is impeded (for details, see Wendt 1994). In light of this, it does not appear in the least surprising that in the EAEU, as Dragneva and Wolczuk put it (2017: 2), "[a]1l member states seek to minimize commitments and maximize flexibility within the common regime". Actually, this problem could be partially solved by strengthening the independence and power of the supranational institution; however, in the situation when the weight of one member stateRussia-significantly surpasses the combined weight of the other member nations, forcing it to observe the Eurasian Economic Commission's regulations appears hardly possible. As a result, already after three years of its existence, the bloc's future development is hampered by the trends noted by Dragneva and Wolczuk (2017: 13-17): first, Russia tends to behave like a hegemon, disregarding the union's rules, second, important questions are primarily dealt with at the intergovernmental rather than supranational level, and third, the implementation of the EAEU's decisions tends to be hindered by the member states' poor domestic governance.

Third, the EAEU seems to be highly centralised around Russia, with almost all the hopes and goals of the other member states being linked to Russia, while their mutual links are mostly inconsiderable. In principle, there seems to be nothing bad or odd about an economic integration group having one leader, however, so far, the world's two most successful integration organisations - the EU and ASEAN-are those that have not been centred on one particular country. Moreover, having all the motives aiming at one state poses a certain danger, since it means that the extent to which the union is able to realise its members' goals strongly depends on a situation in that country at each particular period. Coupled with the points mentioned earlier, it seems fair to say that unlike the EU's 'capability-expectations gap', which is regarded as an institutional weakness (see Hill 1993), a similar gap in the EAEU, if/ when emerges, is likely to be interpreted as having a primarily political origin. 
Acknowledgements For their invaluable comments and suggestions, I am immensely grateful to Peter van Elsuwege and the participants of the panel "Economic Aspects of International Relations in Eurasia" at the First Annual Tartu Conference on Russian and East European Studies (University of Tartu, Estonia), where an earlier version of this essay was presented.

\section{Compliance with ethical standards}

Conflict of interest The author declares that he has no conflict of interest.

\section{References}

BELTA. 2014. Lukashenko: Everything that Happened During Maidan was Wrong and Unconstitutional, 24 September. http://eng.belta.by/president/view/lukashenko-everything-that-happened-duringmaidan-was-wrong-and-unconstitutional-6917-2014. Accessed 2 July 2017.

Birnbaum, Michael. 2014. Putin's Eurasian Economic Union Starts in 2015 with Curtailed Ambitions. The Washington Post, 23 December. https:/www.washingtonpost.com/world/europe/putinseurasian-economic-union-starts-in-2015-with-curtailed-ambitions/2014/12/23/313e7864-8a1b-11e4ace9-47de1af4c3eb_story.html. Accessed 2 July 2017.

Boguslavska, Kateryna. 2015. The First Steps of the Eurasian Economic Union: Disputes, Initiatives and Results. Russian Analytical Digest 170: 9-12.

Bogutsky, Oleg. 2015. Belarus-Ukraine: Strategically Important Neighborhood. In Belarusian Yearbook 2014, ed. Anatoly Pankovsky, and Valeria Kostyugova, 90-96. Vilnius: Lohvinau.

Cadier, David. 2014. Eastern Partnership vs Eurasian Union? The EU-Russia Competition in the Shared Neighbourhood and the Ukraine Crisis. Global Policy 5(1): 76-85.

Charnysh, Volha. 2014. The Real Winner in the Ukraine Crisis. The National Interest, 28 April. http:// nationalinterest.org/feature/the-real-winner-the-ukraine-crisis-10317. Accessed 2 July 2017.

Coalson, Robert. 2014. Despite Ukraine Crisis, Russia Pursues Eurasian Integration Dream. Radio Free Europe/Radio Liberty, 28 May. http://www.rferl.org/content/russias-eurasian-integration-dreamsteams-ahead-despite-ukraine-crisis/25401714.html. Accessed 2 July 2017.

Czerewacz-Filipowicz, Katarzyna, and Agnieszka Konopelko. 2017. Regional Integration Processes in the Commonwealth of Independent States: Economic and Political Factors. Cham: Springer.

Daly, John. 2014. Kazakhstan and Belarus: Buyer's Remorse? In Putin's Grand Strategy: The Eurasian Union and Its Discontents, ed. Frederick S. Starr F, Svante Cornell, 82-97. Washington: Central Asia - Caucasus Institute \& Silk Road Studies Program.

de Micco, Pasquale. 2015. When Choosing Means Losing: The Eastern Partners, the EU and the Eurasian Economic Union. Brussels: European Parliament.

Dragneva, Rilka, and Kataryna Wolczuk. 2012. Russia, the Eurasian Customs Union and the EU: Cooperation, Stagnation or Rivalry?. London: Chatham House.

Dragneva, Rilka, and Kataryna Wolczuk. 2017. The Eurasian Economic Union: Deals, Rules and the Exercise of Power. London: Chatham House.

Economides, Spyros, and James Ker-Lindsay. 2015. 'Pre-Accession Europeanization': The Case of Serbia and Kosovo. Journal of Common Market Studies 53(5): 1027-1044.

Economist Intelligence Unit. 2016. Democracy Index 2015: Democracy in an Age of Anxiety. http://www. isie.tn/wp-content/uploads/2016/01/Economist_Intelligence_Unit-Democracy-Index-2015.pdf. Accessed 2 July 2017.

Engvall, Johan. 2014. Kyrgyzstan and Tajikistan: Next in Line. In Putin's Grand Strategy: The Eurasian Union and Its Discontents, ed. Frederick S. Starr and Svante Cornell, 112-121. Washington: Central Asia - Caucasus Institute \& Silk Road Studies Program.

Engvall, Johan, and Svante E. Cornell. 2015. Asserting Statehood: Kazakhstan's Role in International Organizations. Washington: Central Asia - Caucasus Institute \& Silk Road Studies Program.

Eurasian Economic Commission. 2016a. Vzaimnaya torgovlya tovarami. Statistika Evrazijskogo ehkonomicheskogo soyuza. 2015 god. Statisticheskij byulleten'. Moscow: Eurasian Economic Commission. 
Eurasian Economic Commission. 2016b. Vzaimnaya torgovlya tovarami. Statistika Evrazijskogo ehkonomicheskogo soyuza. Yanvar'-sentyabr' 2016 goda Statisticheskij byulleten'. Moscow: Eurasian Economic Commission.

Falyakhov, Rustem. 2014. Ot Evrazii odni ubytki. Gazeta.Ru, 21 October. http://www.gazeta.ru/business/ 2014/10/17/6264305.shtml. Accessed 2 July 2017.

House, Freedom. 2017. Freedom in the World 2016. Washington: Freedom House.

Golam, Mostafa. 2013. The Concept of "Eurasia": Kazakhstan's Eurasian Policy and Its Implications. Journal of Eurasian Studies 4: 160-170.

Grigoryan, Armen. 2014. Armenia: Joining Under the Gun. In Putin's Grand Strategy: The Eurasian Union and Its Discontents, ed. Frederick S. Starr, and Svante Cornell, 98-109. Washington: Central Asia - Caucasus Institute \& Silk Road Studies Program.

Hedenskog, Jakob, and Korkmaz, Kaan. 2016. The Interests of Russia and Turkey in the NagornoKarabakh Conflict. RUFS Briefing, No. 35.

Hill, Christopher. 1993. The Capability-Expectations Gap, or Conceptualizing Europe's International Role. Journal of Common Market Studies 31(3): 305-328.

Kakachia, Kornely, and Salome Minesashvili. 2015. Identity Politics: Exploring Georgian Foreign Policy Behavior. Journal of Eurasian Studies 6: 171-180.

Kasamara, Valeria, and Anna Sorokina. 2012. Imperial Ambitions of Russians. Communist and PostCommunist Studies 45(3-4): 279-288.

Kazharski, Aliaksei. 2013. Eurasian Regionalism as an Identitary Enterprise: Representations of European Other in Russian Discourse on Eurasian Integration. CEURUS EU-Russia Papers, No. 12.

Keating, Vincent Charles, and Katarzyna Kaczmarska. 2017. Conservative Soft Power: Liberal Soft Power Bias and the 'Hidden' Attraction of Russia. Journal of International Relations and Development. doi:10.1057/s41268-017-0100-6.

Khodasevich, Anton. 2016. Belorusy ne verjat v Evrazijskij sojuz. Nezavisimaya Gazeta, 25 March. http://www.ng.ru/cis/2016-03-25/7_belorussia.html. Accessed 2 July 2017.

Komrakov, Anatoly. 2016. Inostrancy fiksirujut uluchshenie delovogo klimata v RF. Nezavisimaya Gazeta, 22 March. http://www.ng.ru/economics/2016-03-22/1_inostrantsy.html. Accessed 2 July 2017.

Kuchins, Andrew C., Jeffrey Mankoff, and Oliver Backes. 2015. Central Asia in a Reconnecting Eurasia: Kyrgyzstan's Evolving Foreign Economic and Security Interests. Washington: CSIS.

Landesmann, Michael A. 2015. The New North-South Divide in Europe: Can the European Convergence Model Be Resuscitated? In The Triple Challenge for Europe: Economic Development, Climate Change, and Governance, ed. Jan Fagerberg, Staffan Laestadius and Ben R. Martin, 60-89. Oxford: Oxford University Press.

Laruelle, Marlene. 2015. Kazakhstan's Posture in the Eurasian Union. In Search of Serene Sovereignty. Russian Analytical Digest 165: 7-10.

Libman, Alexander, and Evgeny Vinokurov. 2012. Holding-Together Regionalism: Twenty Years of PostSoviet Integration. New York: Palgrave Macmillan.

Libman, Alexander. 2015. Ukrainian Crisis, Economic Crisis in Russia and the Eurasian Economic Union. Munich: MPRA.

Lukashenko, Alexander. 2016. State of the Nation Address of Belarus President Alexander Lukashenko, 21 April. http://president.gov.by/en/news_en/view/alexander-lukashenko-delivers-state-of-thenation-address-on-21-april-13519/. Accessed 2 July 2017.

Malamud, Andrés. 2005. Mercosur Turns 15: Between Rising Rhetoric and Declining Achievement. Cambridge Review of International Affairs 18(3): 421-436.

March, James D., and Johan P. Olsen. 1995. Democratic Governance. New York: Free Press.

Melikyan, Jonny. 2015. Armeniya i Evrazijskij soyuz: ot sotrudnichestva $k$ integracii. Erevan: Caucasus Institute.

Michel, Casey. 2014. Vladimir Putin's Importent Eurasian Union. Foreign Policy, 5 June. http:// foreignpolicy.com/2014/06/05/vladimir-putins-impotent-eurasian-union/. Accessed 2 July 2017.

Mordyushenko, Olga. 2016. Armenija priblizhaetsja k Belorussii. Kommersant, 8 April. http:// kommersant.ru/doc/2957808. Accessed 2 July 2017.

Morozova, Natalia. 2011. The Politics of Russian Post-Soviet Identity: Geopolitics, Eurasianism, and Beyond. Dissertation, Central European University.

Moshes, Arkady. 2014. Belarus' Renewed Subordination to Russia: Unconditional Surrender or Hard Bargain?. Washington: PONARS Eurasia. 
Nazarbayev, Nursultan. 2011. Evrazijskij Sojuz: ot idei k istorii budushhego. Izvestiya, 25 October. http:// iz.ru/news/504908. Accessed 2 July 2017.

Nazarbayev, Nursultan. 2015. State of the Nation Address by President of Kazakhstan Nursultan Nazarbayev, 30. November. http://www.akorda.kz/en/addresses/state-of-the-nation-address-bypresident-of-kazakhstan-nursultan-nazarbayev-november-30-2015. Accessed 2 July 2017.

Popescu, Nicu. 2014. Eurasian Union: The Real, the Imaginary and the Likely. Paris: EU Institute for Security Studies.

Putin, Vladimir. 2011. Novy integracionnyi proekt dlya Evrazii - budushchee, kotoroe rozhdaetsya segodnya. Izvestiya, 3 October. http://izvestia.ru/news/502761. Accessed 2 July 2017.

Putin, Vladimir. 2014. Presidential Address to the Federal Assembly, 4 December. http://en.kremlin.ru/ events/president/news/47173. Accessed 2 July 2017.

Putin, Vladimir. 2015. Presidential Address to the Federal Assembly, 3 December. http://en.kremlin.ru/ events/president/news/50864. Accessed 2 July 2017.

Putz, Catherine. 2015. Kazakhstan Shuts Down Gay Propaganda Law. The Diplomat, 27 May. http:// thediplomat.com/2015/05/kazakhstan-shuts-down-gay-propaganda-law/. Accessed 2 July 2017.

Quinn, Allison. 2015. Russian Officials Slam Anti-Corruption Drive as Attempt to Overthrow Government. The Moscow Times, 9 February. http://www.themoscowtimes.com/news/article/ russian-officials-slam-anti-corruption-drive-as-attempt-to-overthrow-government/515640.html. Accessed 2 July 2017.

Reiter, Svetlana, and Osborn, Andrew. 2017. Anti-Kremlin Protesters Fill Russian Streets, Putin Critic Navalny Jailed. Reuters, 13 June. https://www.reuters.com/article/us-russia-opposition-protestsidUSKBN192167. Accessed 2 July 2017.

Reporters Without Borders. 2017. 2017 World Press Freedom Index. https://rsf.org/en/ranking_table. Accessed 2 July 2017.

Rushton, Katherine. 2014. Russia Cancels Ukraine's Gas Discount and Demands \$1.5bn. The Telegraph, 4 March. http://www.telegraph.co.uk/finance/newsbysector/energy/oilandgas/10676228/Russiacancels-Ukraines-gas-discount-and-demands-1.5bn.html. Accessed 2 July 2017.

Schwab, Klaus, and Xavier Sala-i-Martín. 2015. The Global Competitiveness Report 2015-2016. Geneva: World Economic Forum.

Shendrikova, Diana. 2015. Going Regional the Russian Way: The Eurasian Economic Union between Instrumentalism and Global Social Appropriateness. Milan: ISPI.

Silvius, Ray. 2014. The Russian State, Eurasianism, and Civilisations in the Contemporary Global Political Economy. Journal of Global Faultlines 2(1): 44-69.

Simmons, Katie, Bruce Stokes, and Jacob Poushter. 2015. NATO Publics Blame Russia for Ukrainian Crisis, but Reluctant to Provide Military Aid. In Russia, Anti-Western Views and Support for Putin Surge: Washington, Pew Research Center.

Sivickiy, Arseniy. 2015. Belarus: Muted Integration Euphoria. In The Eurasian Economic Union: Analyses and Perspectives from Belarus, Kazakhstan, and Russia, ed. Felix Hett and Susanne Szkola, 15-19. Berlin: FES.

Smok, Vadzim. 2013. Belarusian Identity: The Impact of Lukashenka's Rule. Minsk: Ostrogorski Centre.

Stratfor. 2013. Russia's Position in the Kyrgyz-Uzbek Border Dispute, 23 January. https://www.stratfor. com/analysis/russias-position-kyrgyz-uzbek-border-dispute. Accessed 2 July 2017.

Tarr, David G. 2016. The Eurasian Economic Union of Russia, Belarus, Kazakhstan, Armenia, and the Kyrgyz Republic: Can It Succeed Where Its Predecessor Failed? Eastern European Economics 54(1): 1-22.

TASS. 2015. Migrant Outflow from Russia not to Be Critical for Russian Economy - Minister, 30 January. http://tass.ru/en/economy/774568. Accessed 2 July 2017.

The Moscow Times. 2015. Officials Suggest Russians Could Face Economic Crisis by 'Eating Less', 2 July. http://www.themoscowtimes.com/article.php?id=514850. Accessed 2 July 2017.

The Moscow Times. 2016. Protests at Russian Embassy in Armenia Over Arms Sales to Azerbaijan, 14 April. http://www.themoscowtimes.com/news/article/protests-at-russian-embassy-in-armenia-overarms-sales-to-azerbaijan/565816.html. Accessed 2 July 2017.

Transparency International. 2017. Corruption Perceptions Index 2016. https://www.transparency.org/ news/feature/corruption_perceptions_index_2016\#table. Accessed 2 July 2017.

UN Human Rights Council. 2014. Human Rights, Sexual Orientation, and Gender Identity, A/HRC/RES/ 27/32. https://documents-dds-ny.un.org/doc/UNDOC/GEN/G14/177/32/PDF/G1417732.pdf?Open Element. Accessed 2 July 2017. 
van der Togt, Tony, Francesco S. Montesano, and Iaroslav Kozak. 2015. From Competition to Compatibility: Striking a Eurasian Balance in EU-Russia Relations. Hague: Clingendael.

Vinokurov, Evgeny. 2014. Mega Deal Between the European Union and the Eurasian Economic Union. Munich: MPRA.

Vinokurov, Evgeny. 2017. Eurasian Economic Union: Current State and Preliminary Results. Russian Journal of Economics 3: 54-70.

Vitkine, Benoît. 2014. Vladimir Putin's Eurasian Economic Union Gets Ready to Take on the World. The Guardian, 28 October. http://www.theguardian.com/world/2014/oct/28/eurasian-economic-unionrussia-belarus-kazakhstan. Accessed 2 July 2017.

Weart, Spencer R. 1998. Never at War: Why Democracies Will Not Fight One Another. New Haven: Yale University Press.

Wendt, Alexander. 1994. Collective Identity Formation and the International State. American Political Science Review 88(2): 384-396.

World Bank. 2017. Doing Business 2017: Equal Opportunity for All. Washington: The World Bank.

Zagorski, Andrey. 2015. Caught between the Economy and Geopolitics. In The Eurasian Economic Union: Analyses and Perspectives from Belarus, Kazakhstan, and Russia, ed. Felix Hett and Susanne Szkola, 4-7. Berlin: FES.

Artem Patalakh is a Doctoral Candidate in Political Studies at the Graduate School of Social and Political Sciences of the University of Milan, Italy. He holds bachelor's and master's degrees in regional studies from MGIMO-University (Moscow, Russia). He publishes on soft power, democracy and human rights promotion, Russian and EU foreign policies and the international politics of the post-Soviet space. 